(․ М. Р. Назаревич, Р. 3. Огоновський, Ю. М. Мельничук, Х. Р. Погранична, Я. М. Ільницький

Львівський національний медичний університет імені Данила Галицького

e-mail: maxnaz34@gmail.com

\title{
Результати дослідження стресових реакцій у хворих із поєднаною травмою середньої зони обличчя після застосування комплексної післяопераційної реабілітації
}

\section{ІНФОРМАЦІЯ}

Надійшла до редакції/Received: 06.06.2020 p.

Ключові слова: ушкодження кісток середньої зони обличчя; стресові реакції; гіпоталамо-гіпофізарна система; транскраніальна електростимуляція; $\beta$-ендорфіни; стресовий індекс Гаркаві; адренокориткотропний гормон; кортизол.

\section{АНОТАЦІЯ}

Резюме. Ушкодження кісток середньої зони обличчя за частотою займають 2-ге місце серед переломів щелепно-лицевої ділянки (ЩЛд). У всіх випадках такі травми супроводжуються множинними, часто багатофрагментарними переломами вилично-орбітального комплексу. Частим ускладненням черепно-мозкової травми (ЧМТ) $€$ порушення чи недостатність функції гіпоталамо-гіпофізарної системи, що не тільки ускладнює перебіг хвороби, але й гальмує процес одужання хворих, і в низці випадків потребує корекції. Частота порушення функції гіпоталамо-гіпофізарної системи унаслідок ЧМТ коливається від 15 до 68 \%. Останнім часом значну увагу науковців звернено на застосування транскраніальної електротерапії. Встановлено, що за її допомогою вдається активувати опіоїдні структури головного мозку та структури гіпоталамо-гіпофізарної ділянки.

Мета дослідження - вивчити ефективність транскраніальної електростимуляції на регуляцію функції гіпоталамо-гіпофізарної системи при реабілітації хворих із травматичними ушкодженнями кісток вилично-орбітального комплексу.

Матеріали і методи. У клінічні спостереження було задіяно 47 хворих, які перебували на лікуванні у Львівській міській комунальній клінічній лікарні швидкої медичної допомоги за період із 2014 до 2018 року. В цих пацієнтів було діагностовано легку черепно-мозковаю травма та тяжку травму щелепно-лицевої ділянки. Хворих, залежно від методів лікування на етапі післяопераційної реабілітації, поділили на контрольну (22 пацієнти) й основну групи (25 пацієнтів). Хворим контрольної групи застосовували традиційні способи консервативного лікування, а хворим основної групи комплекс лікувальних заходів доповнювали курсом транскраніальної електротерапії. Визначення типу загальної неспецифічної адаптаційної реакції проводили за індексом адаптації Л. Х. Гаркаві. У периферійній венозній крові досліджували біохімічні маркери стресу - адренокортикотропний гормон (АКТГ), кортизол та антистресової системи - $\beta$-ендорфіни.

Результати досліджень та їх обговорення. Вміст $\beta$-ендорфінів був вищий за показники норми на 7-му добу в контрольній $(12,73 \pm 1,6)$ пг/мл та основній групах $(15,4 \pm 1,8)$ пг/мл. На 14 -ту добу зростання $\beta$-ендорфінів припинялося в обох клінічних групах. Отримані дані яскраво свідчать про позитивний терапевтичний ефект динамічної електронейростимуляції на стреслімітуючу ендогенну опіатну систему. У хворих із легкою ЧМТ та тяжкою травмою виличноорбітального комплексу вміст АКТГ $(35,67 \pm 3,42)$ пг/мл та кортизолу $(309,9 \pm 12,3)$ нмол/л на 14-ту добу був значно менший в основній групі, ніж у контрольній (АКТГ - $(44,62 \pm 4,37)$ пг/мл; кортизол - $(364,4 \pm 16,3)$ нмол/л). Такі результати можна пояснити тяжкістю отриманих травм, які викликали порушення в роботі гіпоталамогіпофізарної системи. 
При оцінці індексу стресорності виявлено, що на 7-му добу після проведення операційного втручання показники були меншими за 0,3 ум. од. Це вказує на те, що у більшості хворих із поєднаною травмою розвивається стрес-реакція на отриману травму. Результати обстеження на 14-ту добу показали, що стресові реакції зупинялися та переходили в реакцію тренування в обох клінічних групах 3 дещо вищими показниками в основній групі (контрольна група $(0,41 \pm 0,05)$ ум. од.; основна група - $(0,44 \pm 0,040)$ ум.од.

Висновки. Застосування транскраніальної електростимуляції сприяло нормалізації тонусу механізмів антистресового захисту, стимулювало ендодорфінні структури головного мозку, забезпечувало урегулювання викиду стресреалізуючих гормонів у кров та сприяло зниженню рівня стресу та тривожних проявів у пацієнтів у післяопераційному періоді.

Вступ. Ушкодження кісток середньої зони обличчя за частотою займають 2-е місце серед переломів щелепно-лицевої ділянки (ЩЛд), а статистичні показники вказують на досить великий відсоток їх частоти, який досягає від 20 до 35 \% від усіх травм обличчя. А їх основною причиною найчастіше бувають тяжкі дорожньо-транспортні пригоди (до 89,5 \%) та побутові травми [1].

У всіх випадках такі травми супроводжуються множинними, часто багатофрагментарними переломами вилично-орбітального комплексу, верхньої щелепи, кісткової основи носа. Проте спільним для них є не тільки одна анатомічна зона ушкодження, але і те, що у 86-100 \% випадків вони поєднуються із закритою черепно-мозковою травмою [1-10].

Окрім цього, вважаючи, що середня зона обличчя є найбільш клінічно значимою ділянкою обличчя, де проходить ціла низка черепно-мозкових нервів та судин, де існує тісний контакт із твердою мозковою оболонкою, такі травми, за думкою багатьох науковців, створюють безліч ризиків для життя хворих, у тому числі у віддалених після травми періодах та вимагають своєчасної та ефективної їх корекції [1-12].

На думку великої кількості дослідників, поряд із сучасним медикаментозним лікуванням, серед реабілітаційних заходів при поєднаних травмах середньої зони обличчя та ЦНС, велике значення мають фізіотерапевтичні процедури, які можна застосовувати на усіх стадіях захворювання, та завдяки яким можна ефективно корегувати окремі патогенетичні ланки процесу та здійснювати симптоматичне лікування [13-15]. Частим ускладненням ЧМТ $є$ порушення чи недостатність функції гіпоталамо-гіпофізарної системи, що не тільки ускладнює перебіг хвороби, але й гальмує процес одужання хворих і в низці випадків потребує корекції. Частота порушення функції гіпоталамо-гіпофізарної системи унаслідок ЧМТ коливається від 15 до 68 \% [16].

Останнім часом значну увагу науковці звернули на застосування транскраніальної електротерапії, однією із модифікацій якої є транскраніальна електростимуляція. Встановлено, що за її допомогою вдається активувати опіоїдні структури головного мозку та структури гіпоталамо-гіпофізарної ділянки, нормалізувати роботу підкіркових структур головного мозку, що дозволяє оптимізувати синтез нейрогормонів, регулюючих діяльність органів і систем людського організму [17-20].

Метою дослідження було вивчити ефективність транскраніальної електростимуляції на регуляцію функції гіпоталамо-гіпофізарної системи при реабілітації хворих із травматичними ушкодженнями кісток вилично-орбітального комплексу.

Матеріали і методи. У клінічні спостереження було задіяно 47 хворих віком від 18 до 75 років, які перебували на лікуванні у Львівській міській комунальній клінічній лікарні швидкої медичної допомоги за період із 2014 до 2018 року. В цих пацієнтів було діагностовано поєднану травму середньої зони обличчя (легка черепно-мозкова травма та тяжка травма щелепно-лицевої ділянки згідно з класифікацією А. П. Фраєрмана та Ю. Е. Тельмана).

Хворих залежно від методів консервативного лікування на етапі післяопераційної реабілітації поділили на контрольну (22 пацієнтів) і основну групи (25 пацієнтів). Хворим контрольної групи застосовували традиційні способи консервативного лікування, а пацієнтам основної групи комплекс лікувальних 
заходів доповнювали способами, які ми розробили.

Усім хворим на етапі ранньої післяопераційної реабілітації, в період гострої запальної реакції організму на механічну травму призначали стандартну антибіотикотерапію (кліндаміцин - по 600 мг 2 рази на добу упродовж 7-8 днів), знеболювальну та протизапальну терапію (кетопрофен - по 100 мг 2 рази на добу упродовж 5-6 днів), протинабрякову терапію (L-лізину есцинату - внутрішньовенно по 5-10 мл препарату, розведеного у 1020 мл 0,9 \% розчину натрію хлориду, 1 раз на добу упродовж 4-5 днів).

Місцево призначали фізіотерапевтичні процедури: через 1-2 доби після операції застосовували курс УВЧ-терапії на ділянку ураження (процедури тривалістю від 10 до 20 хв щоденно, в субтермічних дозах (із легким відчуттям тепла), на курс лікування 6-7 процедур.

Хворим основної групи для активації центральних мозкових механізмів антистресового захисту (продукції $\beta$-ендорфінів у гіпоталамо-гіпофізарній системі), нормалізації тонусу вегетативної нервової системи застосовано курс транскраніальної електротерапії, яку проводили за допомогою приладу низькочастотної електротерапії «Радіус-01 ФТ» виробництва республіки Білорусія (свідоцтво про державну реєстрацію № 6600/2007). Параметри роботи траскраніальної електростимуляції ДПС=5 \%; 70 Гц; 0,11 мс; тривалість сеансу - 35 хв, 1 раз на добу. Курс лікування - 10 днів (рис.).

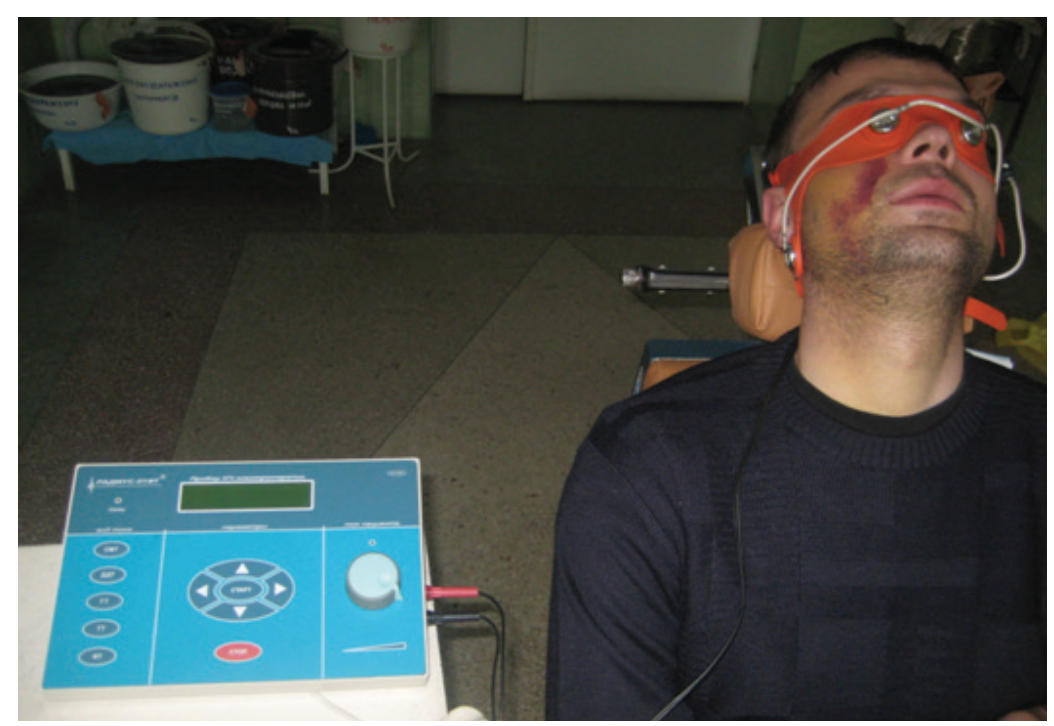

Puc. Сеанс транскраніальної електротерапії у хворого з травматичним ушкодженням кісток середньої зони обличчя.

Визначення типу загальної неспецифічної адаптаційної реакції організму в умовах травматичного стресу проводили за відсотковим вмістом лімфоцитів у лейкоцитарній формулі, відношенням їх до процентного вмісту сегментоядерних нейтрофілів - індексом адаптації Л. Х. Гаркаві.

Критерії адаптаційних реакцій:

а) стрес-реакція: лімфоцити менше ніж 20 \%, індекс адаптації менший ніж 0,3;

б) реакція тренування: лімфоцити - $2127 \%$, індекс адаптації - 0,31-0,50;

в) реакція спокійної активації: лімфоцити 28-33 \%, індекс адаптації - 0,51-0,7;

г) реакція підвищеної активації: лімфоцити - 34-42 \%, індекс адаптації - 0,71-0,90;

д) реакція переактивації: лімфоцити вище ніж 43 \%, індекс адаптації вище ніж 0,90; е) реакція неповноцінної адаптації: лейкоцити периферійної крові - 4,010\%/л та менше.

За ступенем відхилення від норми елементів формули крові визначали рівень реактивності: високий, середній, низький і дуже низький.

У периферійній венозній крові досліджували біохімічні маркери стресу - адренокортикотропний гормон (АКТГ), кортизол та антистресової системи - $\beta$-ендорфіни. Кров для дослідження брали зранку (08:00-9:00). Визначення кортизолу проводили імунохімічним методом за допомогою електрохемілюмінесцентної детекції на аналізаторі 3 тест-системою Cobas 6000, Roche Diagnostics (Швейцарія). Референтні значення - 6,2-19,4 мкг/дл. Коефіцієнт перерахунку мкг/длх27,586 $=$ нмоль/л. Визначення АКТГ (пг/мл) проводи-

ISSN 2311-9624. Клінічна стоматологія. 2020. № 2 
ли імунохімічним методом із хемілюмінесцентною детекцією (CLIA). Використовували аналізатор і тест-систему Immulite (Siemens AG), Німеччина.

Кількісне визначення маркера антистресової системи $\beta$-ендорфіну в плазмі крові (пг/мл) проводили імуноферментним методом за допомогою набору «Uscn Life Science Inc.» (США).

Результати досліджень та їх обговорення. Застосування електростимуляції головного мозку пацієнтам із поєднаною травмою у післяопераційному періоді сприяє підвищенню рівня $\beta$-ендорфінів у плазмі крові, що свідчить про активацію стреслімітуючої ендогенної опіатної системи організму. У хворих вміст $\beta$-ендорфінів був вищий за показники норми на 7-му добу в контрольній $(12,73 \pm 1,6) \mathrm{nг} /$ мл та основній групах $(15,4 \pm 1,8)$ пг/мл. На 14ту добу зростання $\beta$-ендорфінів припинялося в обох клінічних групах. Високі показники $\beta$-ендорфінів у хворих із поєднаною травмою пояснюються відсутністю порушень регуляторних механізмів на рівні гіпоталамо-гіпофізарної системи, які наявні у пацієнтів із тяжкою ЧМТ. Отримані дані яскраво свідчать про позитивний терапевтичний ефект динамічної електронейростимуляції на стреслімітуючу ендогенну опіатну систему (табл. 1).

Таблищя 1. Динаміка вмісту рівня $\beta$-ендорфінів у плазмі крові хворих упродовж післяопераційної реабілітації

\begin{tabular}{|l|c|c|}
\hline \multirow{2}{*}{ Клінічна група } & \multicolumn{2}{|c|}{ Стреслімітуюча система, $\beta$-ендорфіни } \\
& 7 доба & 14 доба \\
\cline { 2 - 3 } & $12,73 \pm 1,6$ & $12,8 \pm 1,8$ \\
\multirow{2}{*}{ Контрольна } & & $\mathrm{p}_{1}=0.977011$ \\
\hline \multirow{2}{*}{ Основна } & $15,4 \pm 1,8$ & $13,13 \pm 1,9$ \\
& $\mathrm{p}_{2}=0,275841$ & $\mathrm{p} 1=0,391673$ \\
& & $\mathrm{p}_{2}=0,900452$ \\
\hline
\end{tabular}

Примітки: 1) $\mathrm{p}_{1}$ - порівняння отриманих показників на 7-му та 14-ту доби дослідження;

2) $\mathrm{p}_{2}$ - статистичну значимість порівнювали між контрольною та основною групами.

Аналіз показників стресреалізуючої системи організму показав, що вміст АКТГ та кортизолу поступово зменшувався в усіх хворих протягом післяопераційної реабілітації. Проте статистично встановлено, що показники пацієнтів, яким застосовували ТЕС-стимуляцію, опускалися до норми значно швидше. У пацієнтів із легкою ЧМТ та тяжкою травмою вилично-орбітального комплексу вміст АКТГ $(35,67 \pm 3,42) \quad$ пг/мЛ та кортизолу $(309,9 \pm 12,3)$ нмол/л на 14-ту добу був значно менший в основній групі, ніж у контрольній (АКТГ - $(44,62 \pm 4,37)$ пг/мл; кортизол - $(364,4 \pm 16,3)$ нмол/л. Такі результати можна пояснити тяжкістю отриманих травм, які викликали порушення в роботі гіпоталамо-гіпофізарної системи. Застосування транскраніальної електростимуляції сприяло врегулюванню викиду стресреалізуючих гормонів у кров та зниженню рівня стресу та тривожних проявів у пацієнтів у післяопераційному періоді (табл. 2).

Таблиия 2. Прояви стрес-реакцій у крові хворих із поєднаною травмою середньої зони обличчя різного ступеня тяжкості

\begin{tabular}{|l|c|c|c|c|}
\hline \multirow{2}{*}{ Клінічна група } & \multicolumn{4}{|c|}{ Стресреалізуюча система } \\
\cline { 2 - 5 } & \multicolumn{2}{|c|}{ АКТГ (пг/мл) } & \multicolumn{2}{c|}{ Кортизол (нмол/л) } \\
\cline { 2 - 5 } & 7 доба & 14 доба & 7 доба & 14 доба \\
\hline \multirow{2}{*}{ Контрольна } & $47,53 \pm 5,34$ & $\begin{array}{c}44,62 \pm 4,37 \\
\mathrm{p}_{1}=0,676333\end{array}$ & $379,5 \pm 16,7$ & $\begin{array}{c}364,4 \pm 16,3 \\
\mathrm{p}_{1}=0,522681\end{array}$ \\
\hline \multirow{2}{*}{ Основна } & $\begin{array}{c}35,67 \pm 3,42 \\
\mathrm{p}_{1}=0,414223 \\
\mathrm{p}_{2}=0,116596\end{array}$ & $362,4 \pm 15,9$ & $309,9 \pm 12,3$ \\
$\mathrm{p}_{2}=0,226877$ & & & 3182 \\
\hline
\end{tabular}

Примітки: 1) $\mathrm{p}_{1}$ - порівняння отриманих показників на 7-му та 14-ту доби дослідження;

2) $\mathrm{p}_{2}$ - статистичну значимість порівнювали між контрольною та основною групами. 
При оцінці індексу стресорності виявлено, що на 7-му добу після проведення операційного втручання показники були меншими за 0,3 ум. од. Це вказує на те, що у більшості хворих із поєднаною травмою розвивається стрес-реакція на отриману травму, що вказує на максимальне напруження систем неспецифічної адаптації організму. Варто відмітити, що у пацієнтів основної групи індекс Гаркаві на 7-му добу відмічалася реакція тренування. Обстеження на 14-ту добу показало, що стресові реакції зупинялися та переходили в реакцію тренування в обох клінічних групах 3 дещо вищими показниками в основній групі (контрольна група - $(0,41 \pm 0,05)$ ум. од.; основна група - $(0,44 \pm 0,040)$ ум. од.) (табл. 3$)$.

таблиця 3. Динаміка індексу стресорності хворих упродовж післяопераційної реабілітації

\begin{tabular}{|l|c|c|}
\hline \multirow{2}{*}{ Клінічна група } & \multicolumn{2}{|c|}{ Стресовий індекс Гаркаві (ум. од.) } \\
\cline { 2 - 3 } & 7 доба & 14 доба \\
\hline Контрольна & $0,27 \pm 00,3$ & $0,41 \pm 0,05$ \\
\hline Основна & $0,29 \pm 0,03$ & $0,44 \pm 0,04$ \\
\hline
\end{tabular}

Висновки. 1. Стрес, який виникає у хворих із поєднаною травмою середньої зони обличчя, як реакція на травму, спричиняє значні зміни у стабільності балансу стресреалізуючої гіпоталамо-гіпофізарної системи.

2. Застосування транскраніальної електростимуляції сприяло нормалізації тонусу меха- нізмів антистресового захисту, стимулювало ендодорфінні структури головного мозку, забезпечувало врегулювання викиду стресреалізуючих гормонів у кров та зниженню рівня стресу та тривожних проявів у пацієнтів у післяопераційному періоді.

\section{(С). Р. Назаревич, Р. З. Огоновский, Ю. М. Мельничук, Х. Р. Погранична, Я. М. Ильницкий}

Львовский национальный медицинский университет имени Данила Галицкого

\section{Результаты исследования стрессовых реакций у больных с сочетанной травмой средней зоны лица после применения комплексной послеоперационной реабилитации}

Резюме. Повреждение костей средней зоны лица по частоте занимают второе место среди переломов челостно-лицевой области (ЧЛО). Во всех случаях такие травмы сопровождаются множественными, часто много-фрагментарными переломами скуло-орбитального комплекса. Частым осложнением черепно-мозговой травмы (ЧМТ) является нарушение или недостаточность функции гипоталамо-гипофизарной системы, что не только осложняет течение болезни, но и тормозит процесс выздоровления больных и в ряде случаев требует коррекции. Частота нарушения функции гипоталамо-гипофизарной системы в результате ЧМТ колеблется от 15 до 68 \%. В последнее время значительное внимание ученых обращено на применение транскраниальной электротерапии. Установлено, что с ее помощью удается активировать опиоидные структуры головного мозга и структуры гипоталамо-гипофизарной области.

Цель исследования - изучить эффективность транскраниальной электростимуляции на регуляцию функции гипоталамо-гипофизарной системы при реабилитации больных с травматическими повреждениями костей скуло-орбитального комплекса.

Материалы и методы. В клинические наблюдения было задействовано 47 больных, находившихся на лечении во Львовской городской коммунальной клинической больнице скорой медицинской помощи за период с 2014 по 2018 год. В этих пациентов было диагностировано легкую черепно-мозковаю травму и тяжелую травму челюстно-лицевой области. Больных, в зависимости от методов лечения на этапе послеоперационной реабилитации, было разделенао на контрольную (22 пациента) и основную группы (25 пациентов). Больным контрольной группы применены традиционные способы консервативного лечения, а больным основной группы комплекс лечебных мероприятий дополнялся курсом транскраниальной электротерапии. Определение типа общей неспецифической адаптационной реакции проводилось по индексу адаптации Л. Х. Гаркави. В периферической венозной крови 
исследовали биохимические маркеры стресса - АКТГ (АКТГ), кортизол и антистрессовой системы $\beta$-эндорфины.

Результаты исследований и их обсуждение. Содержание $\beta$-эндорфинов было выше показателей нормы на 7-е сутки в контрольной $(12,73 \pm 1,6)$ пг/мл и основной группах $(15,4 \pm 1,8)$ пг/мл. На 14-е сутки рост $\beta$-эндорфинов прекращался в обеих клинических группах. Полученные данные ярко свидетельствуют о положительном терапевтическом эффекте динамической электронейростимуляции на стресслимитирующую эндогенную опиатную систему. У больных с легкой чМТ и тяжелой травмой скуло-орбитального комплекса содержание АКТГ $(35,67 \pm 3,42)$ пг/мл и кортизола $(309,9 \pm 12,3)$ нмоль/л на 14-е сутки было значительно меньше в основной группе, чем в контрольной (АКТГ - $(44,62 \pm 4,37)$ пг/ мл, кортизол - $(364,4 \pm 16,3)$ нмоль/л. Такие результаты можно объяснить тяжестью полученных травм, вызвавших нарушения в работе гипоталамо-гипофизарной системы. При оценке индекса стрессорности выявлено, что на 7-е сутки после проведения операционного вмешательства показатели были меньше 0,3 ус. ед. Это указывает на то, что у большинства больных с сочетанной травмой развивается стресс-реакция на полученную травму. Обследование на 14-е сутки показало, что стрессовые реакции останавливались и переходили в реакцию тренировки в обеих клинических группах с несколько более высокими показателями в основной группе (контрольная группа - $(0,41 \pm 0,05)$ ус. ед.; основная группа - $(0,44 \pm 0,040)$ ус. ед.).

Выводы. Применение транскраниальной электростимуляции способствовало нормализации тонуса механизмов антистрессового защиты, стимулировало ендодорфинни структуры головного мозга, обеспечивала урегулирования выброса стресс-реализующих гормонов в кровь и снижению уровня стресса и тревожных проявлений у пациентов в послеоперационном периоде.

Ключевые слова: повреждение костей средней зоны лица, стрессовые реакции, гипоталамо-гипофизарная система, транскраниальная электростимуляция, $\beta$-эндорфины, стрессовые индекс Гаркави, адренокортикотропний гормон, кортизол.

(CM. R. Nazarevych, R. Z. Ohonovskyi, Yu. M. Melnychuk, Kh. R. Pohranychna, Ya. M. Ilnytskyi

Danylo Halytsky Lviv National Medical University

\section{Results of the stress reactions study in patients with combined injuries of the midface area after using of complex postoperative rehabilitation}

Summary. The frequency of the midface bone demages area occupy the second place among the all maxillofacial fractures. In all cases, these injuries are accompanied by multiple, often multi-fragmented fractures of zygomatic-orbital complex. The most frequent complication of the cranial-brain trauma is disorder or hypofunction of hypothalamic-pituitary system, which not only complicates the disease, but also slows down the recovery of patients and in some cases requires correction. The frequency of hypothalamic-pituitary system dysfunction due to the cranial-brain trauma ranges from 15 to $68 \%$.

Recently, considerable attention of scientists have been paid to transcranial electrotherapy application. It has been found that this method is able to activate the opioid structures of the brain and the structures of the hypothalamic-pituitary area.

The aim of the study - to learn the effectiveness of transcranial electrical stimulation on the regulation of hypothalamic-pituitary system function in the rehabilitation of patients with traumatic injuries of zygomaticorbital complex.

Materials and Methods. 47 patients were under our observation at Lviv City Municipal Clinical Emergency Hospital during the period from 2014 to 2018. These patients underwent mild brain injury and severe trauma to the maxillofacial area. Patients, depending on the methods of treatment at the stage of postoperative rehabilitation, were divided into control ( 22 patients) and the main group (25 patients). Patients of the control group underwent traditional methods of conservative treatment, and management of the main group patients was supplemented by a course of transcranial electrotherapy. Determination of general nonspecific adaptation reaction type was performed using the adaptation index of Garkavi L. H. Biochemical markers of stress - adrenocorticotropic hormone (ACTH), cortisol and antistress systems - $\beta$-endorphins were identified in peripheral venous blood.

Results and Discussion. On the 7th day $\beta$-endorphin content was higher than normal in the control $(12.73 \pm 1.6) \mathrm{pg} / \mathrm{ml}$ and the main groups $(15.4 \pm 1.8) \mathrm{pg} / \mathrm{ml}$. On the 14 th day, the growth of $\beta$-endorphins was stopped in both clinical groups. The obtained data clearly indicate on a positive therapeutic effect of dynamic electroneurostimulation on the stress-limiting endogenous opiate system. 
In patients with mild cranial-brain trauma and severe zygomatic-orbital complex injury content of ACTH $(35.67 \pm 3.42) \mathrm{pg} / \mathrm{ml}$ and cortisol $(309.9 \pm 12.3) \mathrm{nmol} / \mathrm{L}$ on the 14th day was significantly lower in the main group than in the control group (ACTH - $(44.62 \pm 4.37) \mathrm{pg} / \mathrm{ml}$; cortisol - $(364.4 \pm 16.3) \mathrm{nmol} / \mathrm{l})$. Such results can be explained by the severity of the injuries, which caused disturbances in the work of the hypothalamic-pituitary system.

During the evaluation of the stress index, it was found that on the 7th day after the surgery, the indicators were less than 0.3 conventional units (c.u.). This indicates that the majority of patients with combined trauma develop a stress response to the trauma. Examination on day 14 showed that stress reactions had stopped and turned into a training response in both clinical groups with slightly higher rates in the main group (control group - $(0.41 \pm 0.05)$ c.u.; main group $-0.44 \pm 0.040)$ c.u. $)$.

Conclusions. It can be concluded that the application of transcranial electrical stimulation contributed to the normalization of the anti-stress mechanisms tone, stimulated endodorphic structures of the brain, provided regulation of the stress-releasing hormones in blood and reducing of the stress level and anxiety of patients in the postoperative period.

Key words: midface bone damage; stress reactions; hypothalamic-pituitary system; transcranial electrical stimulation; $\beta$-endorphins; Harkavi stress index; adreno-corticotropic hormone; cortisol.

\section{СПИСОК ЛІТЕРАТУРИ}

1. Суюнова Д. Д. Клинико-диагностические и терапевтические особенности сочетанной черепнолицевой травмы: дисс. ... канд. мед. наук : [спец.] 14.00.21 «Стоматология», 14.01.11 «Нервные болезни». - М., 2014. - 147 с.

2. Характеристика переломів вилицевого комплексу за архівними даними 2006-2010 рр. порівняно 3 попередніми роками / В. О. Маланчук, І. П. Логвиненко, Н. М. Тімощенко, Ю. В. Чепурний // Новини стоматології. - 2012. - № 4. - С. 46-51.

3. Klenk G. Etiology and patterns of facial fractures in the United Arab Emirates / G. Klenk, A. Kovacs // The Journal of Craniofacial Surgery. - 2003. - Vol. 14, No. 1. - P. 78-84.

4. Харитонов Д. Ю. Сочетанные кранио-фациальные повреждения у детей: организационные и методологические подходы к диагностике, лечению и реабилитации (клиническое исследование) : автореф. дисс. на соискание уч. степени д-ра мед. наук : [спец.] 14.00.21 «Стоматология». - Воронеж, 2008. -43 c.

5. Головко К. П. Современный подход к комплексному лечению сочетанных повреждений челюстно-лицевой области: дисс. ... д-ра мед. наук : [спец.] 14.01.17 «Хирургия», 14.00.14 «Стоматология». - СПб., 2016. -331 c.

6. Азарченко К. Я. Диагностика переломов скулоорбитального комплекса // Сборник тезисов докладов V Международной конференции челюстно-лицевых хирургов и стоматологов. - СПб., 2007. C. 16.

7. Власов А. М. Диагностика и лечение сочетанной черепно-мозговой и челюстно-лицевой травмы : автореф. дисс. на соискание уч. степени канд. мед. наук : [спец.] 14.00.21 «Стоматология», 14.00.28 «Нейрохирургия». М., 2005. - 27 с.

8. Боймурадов Ш. А. Сравнительный анализ результатов лечения больных с сочетанными травмами костей носа и повреждениями головного мозга / Ш. А. Боймурадов // Российская оториноларингология. - 2009. - № 3. - С. 31-33.

9. Белевитин А. Б. Современные технологии улуч- шения результатов лечения пострадавшых с кранио-фациальными повреждениями / А. Б. Белевитин, К. П. Головко, Д. Ю. Мадай // Вестник Российской военно-медицинской академии. - 2009. - № 1. С. 963-964.

10. Христофорандо Д. Ю. Особенности патогенеза и лечения сочетанной черепно-лицевой травмы : дисс. ... д-ра мед. наук : [спец.] 14.00.14 «Стоматология", 14.01.11 «Нервные болезни». Ставрополь, 2012. - 233 с.

11. Asymmetric skull deformity in children with cerebral palsy: frequency and correlation with postural abnormalities and deformities / M. Kawakami, M. Liu, T. Otsuka [et al.] // The Journal of Rehabilitation Medicine. - 2013. - Vol. 45, No. 2. - P. 149-153.

12. Лечебная тактика при повреждении околоносовых пазух у пострадавших с тяжелой сочетанной травмой / В. Р. Гофман, К. П. Головко, И. М. Самохвалов, Ю. Ю. Козадаев // Российская оториноларингология. - 2010. - № 3. - С. 52-63.

13. Физиотерапевтические методы лечения, применяемые при травмах челюстно-лицевой области. Их значение в периоде реабилитации больных с травмами лица и челюстей / Е. В. Афанасьев, А. Н. Галкин, Е. Д. Костригина // Сборник научных трудов по материалам Международной научно-практической конференции «Интеграционные процессы мирового научно-технологического развития» (29 ноября 2017 г., Белгород). - 2017. - С. 58-61.

14. Three-dimensional evaluation of postoperative swelling in treatment of zygomatic bone fractures using two different cooling therapy methods: a randomized, observer-blind, prospective study / Ali Modabber, M. Rana, A. Ghassemi [et al.] // Trials. - 2013. - No. 14 (238). $-10 \mathrm{p}$.

15. Физиотерапия в неврологии / А. М. Гурленя, Г. Е. Багель, В. Б. Смычек // М. : Мед. лит., 2008. - 296 с. 16. Hypothalamopituitary disfunction following traumatic brain injury and aneurysmal subarachnoid hemorrhage: a systematic review / H. J. Schneider, I. Kreitschmann-Andermahr, E. Ghigo [et al.] // The 
Journal of the American Medical Association. - 2007. No. 298. - Р. 1429-1438.

17. Лебедев В. П. Влияние транскраниальной электростимуляции эндорфинных структур мозга крыс на функциональную активность гепатоцитов при их токсическом повреждении / В. П. Лебедев, М. В Мелихова, С. Е. Колбасов // Российский физиологический журнал имени И. М. Сеченова. - 2000. - Т. 86, № 11. - С. 1449-1457.

18. Антипова О. А. Транскраниальная электростимуляция в комплексном лечении больных пародонтитом : дисс. ... канд. мед. наук: [спец.] 14.00.21 «Стоматология». - Волгоград, 2005. - 118 с.

\section{REFERENCES}

1. Suyunova, D.D. (2014). Kliniko-diagnosticheskiye i terapevticheskiye osobennosti sochetannoy cherepnolitsevoy travmy [Clinical diagnostic and therapeutic features of combined craniofacial injury]. Candidate's thesis. Moscow [in Russian].

2. Malanchuk, V.O., Lohvynenko, I.P., Timoshchenko, N.M., \& Chepurnyi, Yu.V. (2012). Kharakterystyka perelomiv vylytsevoho kompleksu za arkhivnymy danymy 2006-2010 rr. porivniano z poperednimy rokamy [Characteristics of fractures of the cheekbone complex according to archival data of 20062010 compared to previous years]. Novyny stomatolohii - Dentistry News, 4, 46-51 [in Ukrainian].

3. Klenk, G., \& Kovacs, A. (2003). Etiology and patterns of facial fractures in the United Arab Emirates. The Journal of Craniofacial Surgery, 14, 1, 78-84.

4. Kharitonov, D.Yu. (2008). Sochetannyye kraniofatsialnyye povrezhdeniya u detey: organizatsionnyye i metodologicheskiye podkhody $\mathrm{k}$ diagnostike, lecheniyu i reabilitatsii (klinicheskoye issledovaniye) [Combined craniofacial lesions in children: organizational and methodological approaches to diagnosis, treatment and rehabilitation (clinical study)]. Extended abstract of Candidate's thesis. Voronezh [in Russian].

5. Golovko, K.P. (2016). Sovremennyy podkhod k kompleksnomu lecheniyu sochetannykh povrezhdeniy chelyustno-litsevoy oblasti [A modern approach to the complex treatment of combined injuries of the maxillofacial region]. Doctor's thesis. Saint-Petersburg [in Russian].

6. Azarchenko, K.Ya. (2007). Diagnostika perelomov skuloorbitalnogo kompleksa [Diagnosis of fractures of the zygomatic orbital complex]. Sbornik tezisov dokladov V Mezhdunarodnoy konferentsii chelyustnolitsevykh khirurgov $i$ stomatologov - Abstracts of the Reports of the V International Conference of Maxillofacial Surgeons and Dentists. Saint-Petersburg [in Russian].

7. Vlasov, A.M. (2005). Diagnostika i lecheniye sochetannoy cherepno-mozgovoy i chelyustno-litsevoy travmy [Diagnostics and treatment of combined craniocerebral and maxillofacial trauma]. Extended abstract of Candidate's thesis. Moscow [in Russian].

8. Boymuradov, S.H. (2009). Sravnitelnyy analiz rezultatov lecheniya bolnykh s sochetannymi travmami kostey nosa i povrezhdeniyami golovnogo mozga [Comparative analysis of the results of treatment of patients with combined injuries of the nasal bones
19. Баркова С. В. Эффективность применения транскраниальной электростимуляции в комплексном лечении больных красным плоским лишаем слизистой оболочки полости рта : дисс. ... канд. мед. наук: [спец.] 14.00.21 «Стоматология». - Волгоград, 2007. -105 c.

20. Рогова Н. В. Транскраниальная электростимуляция эндорфинергических структур мозга (ТЭСтерапия) - новый метод лечения больных сахарным диабетом / Н. В. Рогова // Вестник Волгоградского государственного медицинского университета. 2008. - № 2 (26). - С. 53-55.

and brain injuries]. Rossiyskaya otorinolaringologiya Russian Otorhinolaryngology, 3, 31-33 [in Russian].

9. Belevitin, A.B., Golovko, K.P., \& Maday, D.Yu. (2009). Sovremennyye tekhnologii uluchsheniya rezultatov lecheniya postradavshykh s kranio-fatsialnymi povrezhdeniyami [Modern technologies for improving the results of treatment of victims with craniofacial injuries]. Vestnik Rossiyskoy voyenno-meditsinskoy akademii - Bulletin of the Russian Military Medical Academy, 1, 963-964 [in Russian].

10. Khristoforando, D.Yu. (2012). Osobennosti patogeneza i lecheniya sochetannoy cherepno-litsevoy travmy [Features of the pathogenesis and treatment of combined craniofacial injury]. Doctor's thesis. Stavropol [in Russian].

11. Kawakami, M., Liu, M., Otsuka, T., Wada, A., Uchikawa, K., Aoki, A., \& Otaka, Y. (2013). Asymmetric skull deformity in children with cerebral palsy: frequency and correlation with postural abnormalities and deformities. The Journal of Rehabilitation Medicine, $45,2,149-153$.

12. Gofman, V.R., Golovko, K.P., Samokhvalov, I.M., \& Kozadayev, Yu.Yu. (2010). Lechebnaya taktika pri povrezhdenii okolonosovykh pazukh u postradavshikh s tyazheloy sochetannoy travmoy [Therapeutic tactics for damage to the paranasal sinuses in patients with severe combined trauma]. Rossiyskaya otorinolaringologiya Russian Otorhinolaryngology, 3, 52-63 [in Russian].

13. Afanasyev, Ye.V., Galkin, A.N., \& Kostrigina, Ye.D. (2017). Fizioterapevticheskiye metody lecheniya, primenyayemyye pri travmakh chelyustno-litsevoy oblasti. Ikh znacheniye $\mathrm{v}$ periode reabilitatsii bolnykh s travmami litsa i chelyustey [Physiotherapeutic methods of treatment used for injuries of the maxillofacial region. Their significance in the period of rehabilitation of patients with injuries of the face and jaw]. Sbornik nauchnykh trudov po materialam Mezhdunarodnoy nauchno-prakticheskoy konferentsii "Integratsionnyye protsessy mirovogo nauchno-tekhnologicheskogo razvitiya-Collection of Scientific Papers on the Materials of the International Scientific and Practical Conference "Integration Processes of World Scientific and Technological Development. (29.11. 2017), Belgorod [in Russian]. 14. Modabber, A., Rana, M., Ghassemi, A., Gerressen, M., Gellrich, N.C., Hölzle, F., \& Rana, M. (2013). Three-dimensional evaluation of postoperative swelling in treatment of zygomatic bone fractures using two different cooling 


\section{Хірургічна стоматологія}

therapy methods: a randomized, observer-blind, prospective study. Trials, 14 (238), 10.

15. Gurlenya, A.M., Bagel, G.Ye., \& Smychek, V.B. (2008). Fizioterapiya $v$ nevrologii [Physiotherapy in neurology]. Moscow: Med. lit. [in Russian].

16. Schneider, H.J., Kreitschmann-Andermahr, I., Ghigo, E., Stalla, G.K., \& Agha, A. (2007). Hypothalamopituitary disfunction following traumatic brain injury and aneurysmal subarachnoid hemorrhage: a systematic review. The Journal of the American Medical Association, 298, 1429-1438.

17. Lebedev, V.P., Melikhova, M.V., \& Kolbasov, S.Ye. (2000). Vliyaniye transkranialnoy elektrostimulyatsii endorfinnykh struktur mozga krys na funktsionalnuyu aktivnostgepatotsitovpriikh toksicheskompovrezhdenii [The effect of transcranial electrostimulation of rat endorphin brain structures on the functional activity of hepatocytes during their toxic damage]. Rossiyskiy fiziologicheskiy zhurnal imeni I.M. Sechenova - I. Sechenov Russian Physiological Journal, 86, 11, 14491457 [in Russian].
18. Antipova, O.A. (2005). Transkranialnaya elektrostimulyatsiya $\mathrm{v}$ kompleksnom lechenii bolnykh parodontitom [Transcranial electrical stimulation in the complex treatment of patients with periodontitis]. Candidate's thesis. Volgograd [in Russian].

19. Barkova, S.V. (2007). Effektivnost primeneniya transkranialnoy elektrostimulyatsii $\mathrm{v}$ kompleksnom lechenii bolnykh krasnym ploskim lishayem slizistoy obolochki polosti rta [The effectiveness of transcranial electrical stimulation in the complex treatment of patients with lichen planus of the oral mucosa]. Candidate's thesis. Volgograd [in Russian].

20. Rogova, N.V. (2008). Transkranialnaya elektrostimulyatsiya endorfinergicheskikh struktur mozga (TES-terapiya) - novyy metod lecheniya bolnykh sakharnym diabetom [Transcranial electrical stimulation of endorphinergic brain structures (TES-therapy) - a new method of treating patients with diabetes mellitus]. Vestnik Volgogradskogo gosudarstvennogo meditsinskogo universiteta - Bulletin of the Volgograd State Medical University, 2 (26), 53-55 [in Russian]. 